\title{
Trapdoor Pericardiotomy
}

\author{
Sınırlı Perikardiyotomi
}

Hakan Bingöl

Clinic of Cardiovascular Surgery, Karabük Medical Hospital, Karabük, Turkey

\section{INTRODUCTION}

Coronary by-pass surgery is routinely performed on the beating heart following median sternotomy in surgical practice. Pericardiotomy is usually done in an inverse (T) shape in the classical approach to beating heart surgery of the left internal thoracic artery (LITA). Hemodynamic instability may occur during elevation of the heart for exposure of th e left anterior descending artery (LAD). Herein, we describe a limited pericardiotomy technique in LITALAD anastomosis for eliminating hemodynamic derangement.

\section{SURGICAL TECHNIQUE}

Following harvesting of LITA, redundant adipose tissue on the left side of the midline on the pericardium is dissected and removed. A three or four centimeters length of trapdoor pericardiotomy is carried out just above the level of the planned distal anastomosis on the LAD artery (Figure 1). Two stay sutures on both margins of the pericardium are placed, plicated and positioned, thus the LAD artery is well exposed without any hemo-

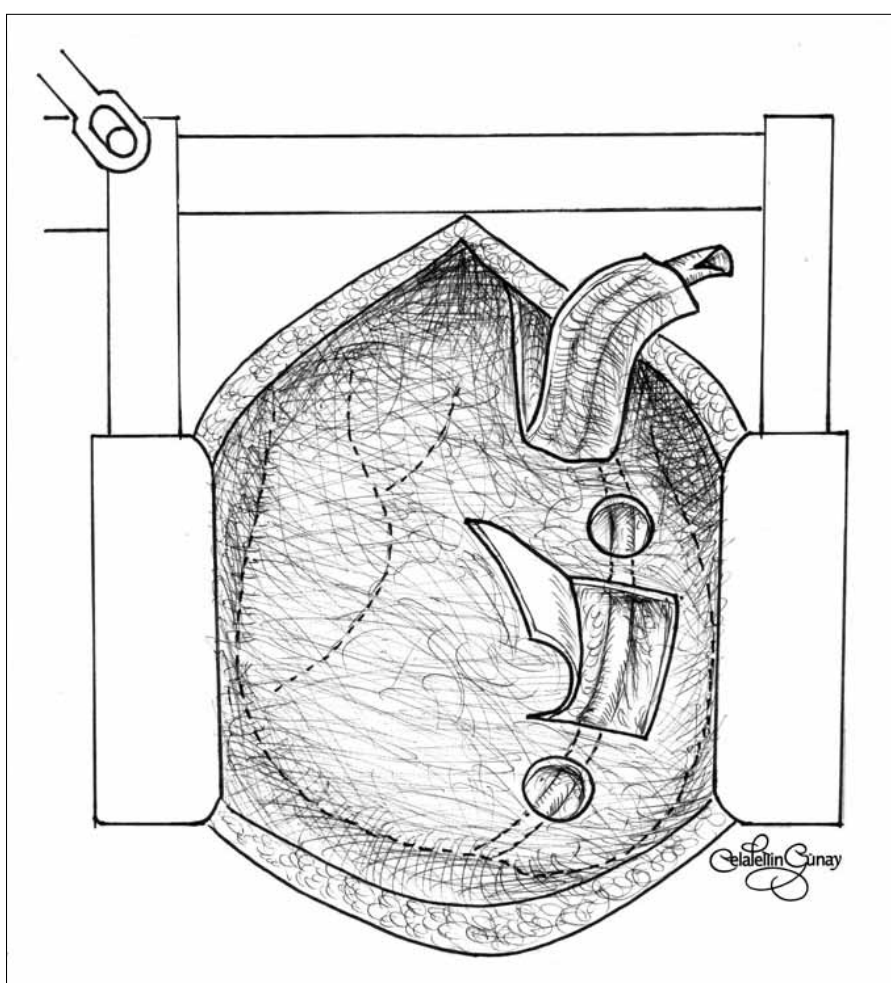

Figure 1. The schematic description trapdoor pericardiotomy dynamic derangement. Proximal and distal control of the LAD artery is achieved through this small hole in the pericardium. I usually use small atraumatic bulldog clamps. Snaring of the LAD artery is rarely required. An intra-coronary shunt is not routinely used. Stabilisation of the heart is achieved by an Octopus device (Axius Vacuum 2 Stabilizer System; Guidant,Santa Clara, California; or Octopus 3; Medtronic, Minneapolis,Minnesota; or Estech equipment). Then arteriotomy of the LAD and distal anastomosis are done in the classical manner (Figure 2). Bleeding control is meticilously done and fixation sutures of LITA are placed. A plicated segment of pericardium is closed over the anastomosis region (Figure 3).

\section{DISCUSSION}

Performing LITA-LAD anastomosis by beating heart coronary artery surgery is a more demanding procedure than by conventional CABG. Despite local tissue stabilization, the heart's natural motion and potential for hemodynamic derangement during cardiac elevation continues to be concerns for the

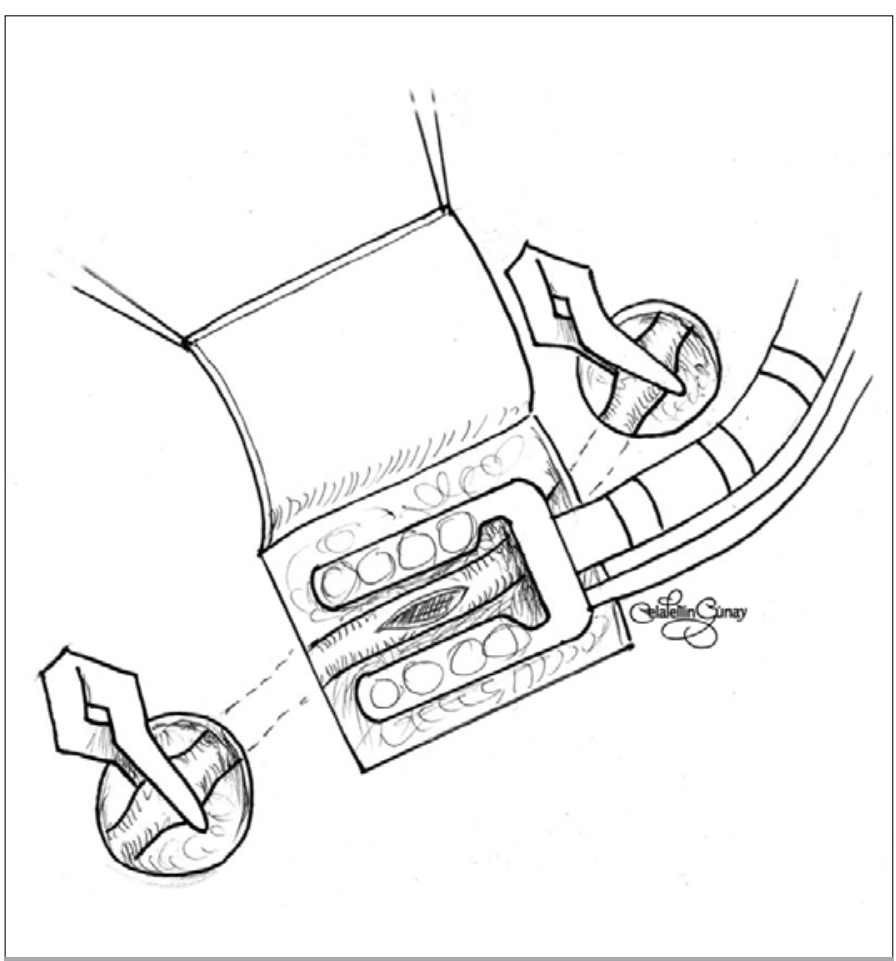

Figure 2. Proximal and distal clamping and stabilisation of LAD artery LAD: Left anterior descending artery

Received Date / Geliş Tarihi: 12.04.2013 Accepted Date / Kabul Tarihi: 29.05.2013 C) Telif Hakkı 2013 AVES Yayınclık Ltd. Şti. Makale metnine www.jarem.org web sayfasından ulaşılabilir. C Copyright 2013 by AVES Yayınclik Ltd. Available online at www.jarem.org 


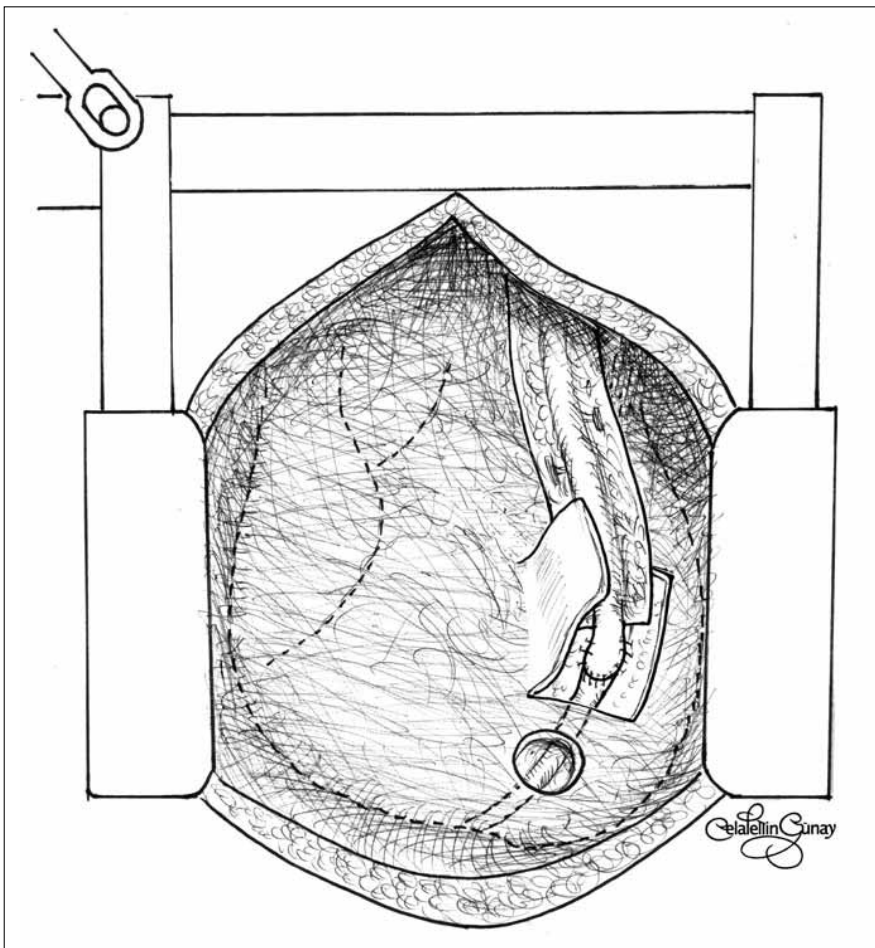

Figure 3. The schematic figure after completing the distal anastomosis quality of the distal anastomosis. Hemodynamic derangement is much more common during lateral and posterior wall revascularizations. Therefore, low cardiac output states may occur due to coronary air embolism and these patients may require intra-aortic balloon pump due to hemodynamic derangement. Thus, conversion to conventional CABG would be necessary $(1,2)$. Hemodynamic derangement may develop during elevation of the heart for exposure of the LAD artery in the classical approach. Limited trapdoor pericardiotomy may completely eliminate the risk of hemodynamic derangement caused by elevation of the heart. Trapdoor pericardiotomy may also reduce adhesion of the heart to surrounding tissues, especially beneath the sternum, and this significantly reduces the risk of reoperation of the heart.

\section{REFERENCES}

1. Arom KV, Flavin TF, Emery RW, Kshettry WR, Janey PA, Petersen RJ. Safety and efficacy of off-pump coronary artery bypass grafting. Ann Thorac Surg 2000; 69: 704-10. [CrossRef]

2. Edmunds LH Jr. Why cardiopulmonary bypass makes patients sick: strategies to control the blood-synthetic surface interface. In: Karp RB, Laks H,Wechsler AS, editors. Adv Card Surg vol. 6. St. Louis: Mosby; 1995.p.131-67. 